\title{
EEN DERDE ELEMENT IN DEN INTEREST.
}

\section{(Ingezonden.)}

Voor zoover mij bekend is, hebben de Staathuishoudkundigen tot heden niet meer dan twee elementen in den interest weten te ontdekken: de eigenlijke huurwaarde van het kapitaal on de verzekeringpremie tegen verlies. Ik meen echter, dat de thoorie van den interest de onderscheiding van nog een derde element vordert, en zal trachten de beteekenis daarvan in breede trekken te schetsen. Daarbij zal ik geheel dogmatisch te werk gaan, trachtende niets uit het oog te verliezen wat reeds op goede gronden als staathuishoudkundige waarheid werd vastgesteld, zonder evenwel telkens in herinnering te brengen wie een en ander reeds vroeger gezegd hebben. Van verwijzingen en citaten wensch ik mij derhalve zooveel mogelijk te onthouden, niet alleen omdat mijn tegenwoordig plan een minder breede opzetting vordert, maar vooral omdat eene proeve van een critische ontwikkeling der leer van den rentestand reeds door Mr. J. J. I. Harte is geschreven, en zulks op inderdaad talentvolle wijze. $\left({ }^{*}\right)$

Ik kan mij hier derhalve strikt bepalen tot de theorie, en al aanstonds de richting aanwijzen, waarin het bedoelde derde element te zoeken is.

Het vraagstuk dat $\mathrm{ik}$ heb te behandelen, maakt namelijk deel uit van het algemeener onderzoek naar den invloed dien veranderingen in de koopkracht van het ruilmiddel dat tevens waardemeter en standaard van waarde is op de verschillende economische verhoudingen uitoefenen.

Deze onderscheiding is noodig. Bij alle op de natuur van het geld betrekking hebbende onderzoekingen moet men toch de verschillende functies die het vervult deugdelijk onderscheiden. 'Ten aanzien bijv. van een ruilmiddel, dat niet tevens waarde-

(") Mr. J. J. I. Harte, De Rentestand. Utrceht P. W. van de Weijer. 
meter is, teekenmunt, om lets to noemen, heeft verandering in koopkracht geen verstaanbaren zin dan in zoover als het bedoelde ruilmiddel den waardemeter verbeeld $t$, maar de ruilwaarde van een waardemeter die niet tevens ruilmiddel is, bijv. als wij het koren tot onzen waardemeter verheffen wilden, zou geen koopkracht heeten kunnen. Voorts heeft verandering in de koopkracht van het ruilmiddel alleen beteekenis in zoover als de waardemeter van het verleden of van het heden tevens de waardemeter van het heden of van de toekomst is, m. a. w. in zoover als de waardemeter tevens standaard van waarde is.

Maar terwijl wij nu op eenige economische gevolgen van veranderingen in de koopkracht van het ruilmiddel te wijzen hebben, ligt toch een belangrijk deel dier invloeden buiten den kring van ons tegenwoordig onderzoek, met name voor zooveel betreft de financieele verhouding tusschen de groote factoren in de algemeene productie: het verband tusschen goederenprijzen, ondernemingswinsten, arbeidsloonen, pacht van landerijen en huur van vaste goederen, benevens inkomsten van renteniers en andere inkomsten van dien aard ligt buiten ons bestek. Wij zullen ons geheel hebben te beperken tot de vraag, of aan verandering in de koopkracht van het ruilmiddel eenige invloed behoort te worden toegekend op de rente van uitgeleende kapitalen, waarbij de geldswaarde dier kapitalen van zelf mede onze aandacht trekken zal.

Wanneer ons onderzoek ten aanzien van dezen laatsten invloed eenige wijziging van de gangbare theorie on vermijdelijk maakt, zal de leer van de verhouding tusschen de groote factoren in de algemeene productie (grondbezit, kapitaal en arbeid) in geval van verandering in de koopkracht van het ruilmiddel, daarnaar mede gewijzigd moeten worden.

Wanneer wij van de koopkracht van het ruilmiddel spreken, bedoelen wij de verhouding waarin het ruilmiddel dat tevens tot waardemeter dient tegen andere zaken of tegen het gebruik van andere zaken geruild wordt. Die verhouding hangt, volgens bekende beginsels, van drie factoren af, en wel in omgekeerde evenredigheid: eerstens van de hoeveelheid waarin het ruilmiddel dat tevens waardemeter is, voorhanden is, in de tweede plaats van de mate waarin het door andere middelen die het ruilen vergemakkelijken vervangen wordt (boekcrediet, niet door metaal gedekte bankbilletten of muntpapier, als ruilmiddel circuleerende bewijsstukken van crediet, bijp. wissels, accepten of zelfs effecten, 
voorts afrekeningen op termijn), in de derde plaats van het aantal malen dat een gegeven hoeveelheid ruilmiddel van hand tot hand gaat om een gegeven hoeveelheid omzet te bewerkstelligen. S. Mill noemt dit, ondanks de heldere uiteenzetting zijner bedoeling, „rapidity of circulation", wat ten onrechte zou doen denken, dat de absolute intensiteit van den ruilmiddel-omzet bedoeld werd, die voor de koopkracht van het ruilmiddel integendeel geen gewicht in de schaal legt, en slaat daarom voor, dezen factor in de geldswaarde: , the efficiency of money" te noemen. Niet het aantal malen dat het geld in zekeren tijd van hand tot hand gaat, maar het aantal malen dat het in zekeren tijd van hand tot hand gaat voor dezelfde goederen, vóór dat zij in consumptie komen, bepaalt mede de waarde van het ruilmiddel, en wel in dien zin, dat hoe meer keeren het ruilmiddel overgaat, des te geringer zijn koopkracht wordt. Eéne hoeveclheid ruilmiddel telt voor drie, vier of meer hoeveelheden.

Verandering in de koopkracht van het ruilmiddel zal derhalve van wijziging in elk dezer drie factoren kunnen afhangen.

Formuleert men nu de vraag, of eene verandering in de koopkracht van het ruilmiddel dat tevens waardemeter is - stel bijv. het goud - eenigen invloed uitoefent op de rente van in gebruik gegeven kapitalen, en zoo ja, welken, dan heeft men in deze vraag zelve reeds eene belangrijke onderscheiding gemaakt. Ik bedoel die tusschen geld als ruilmiddel en waardemeter, en geld in den zin van leenbaar kapitaal. Aan de omstandigheid, dat leenbaar kapitaal vaak met den naam van geld wordt aangeduid, dat tevens de gewone naam is roor het ruilmiddel, is veel misverstand te wịten. En vaak heeft men ten onrechte, en alleen door die verkeerde terminologie misleid, uit de waarde van het geld in den zin van ruilmiddel (koopkracht dus) iets afgeleid voor de waarde van het geld in den zin van leenbaar kapitaal (den rentestand) of omgekeerd. Maar ook in dit laatste (het leenbaar kapitaal) onderscheide men; er zijn tweeërlei soort van kapitalen, on, gelijk Harte terecht heeft opgemerkt en duidelijk aangetoond, dien ten gevolge ook niet één, maar twee rentestanden. Deze onderscheiding verklaart veel schijnbaar tegenstrijdigs in de bewegingen van den rentestand.

Er zijn inderdaad twee soorten van kapitalen: de eene soort is het dadelijk opeischbaar kapitaal, de andere het op langen termijn uitgeleende. De eerste heeft met het ruilmiddel althaus dit uitstande dat ze beschikbaar of in gebruik gegeven ruilmiddel is, de 
andere omvat alle door arbeid verworven en niet voor improductieve consumptic bestemde rijkdommen, waarvan het ruilmiddel slechts een onderdeel uitmaakt. Deze tweede soort van kapitalen, waarvan ook het leenbaar geld een modus wezen zou, waro 't niet dat wij dit ter wille van zijn bizondere eigenschappen geheel afzonderlijk moeten houden, deze tweede soort, zeg ik, die derhalve alle kapitalen omvat met uitzondering van het leenbaar ruilmiddel, wordt wel meestal in den vorm van geld overgedragen, maar de reden waarom 't wordt opgenomen is niet om in eene behoefte aan ruilmiddel te voorzien, maar om te voorzien in eene behoefte aan grondstoffen en werktuigen voor de industrie en in een fonds om den arbeider er uit te onderhouden. Dit verschil in aard tusschen het op korten en het op langen termijn leenbaar kapitaal is van het uiterste gewicht, gelijk wij straks zien zullen. Van ondergeschikten aard is de omstandigheid, dat de leening op korten termijn vaak het karakter van aankoop eener schuldvordering heeft (bij het disconteeren van wissels of promessen). Dien ten gevolge heeft de betaling der huur in dat geval bij de uitleening plaats. Maar bij andere soortgelijke leeningen (beleening of prolongatie) leeft de voldoening der huur van het kapitaal in termijnen plaats, even als bij de leeningen op langen termijn. De wijze waarop de interest vergoed wordt is dan ook eene quaestie van formeelen aard, zij 't ook dat wij dit punt almede niet uit het oog mogen verliezen.

$\mathrm{Na}$ deze onderscheidingen gemaakt te hebben, geloof ik, dat wij behoorlijk voorbereid zijn, om het antwoord te zoeken op de vraag, of verandering in de koopkracht van het ruilmiddel eenigen invloed op den rentestand uitoefent en zoo ja, welken. Maar, nauwlijks trachten wij dat te vinden, of wij zien ons voor de noodzakelijkheid geplaatst om nieuwe onderscheidingen te maken. Als wij van verandering in de koopkracht van het ruilmiddel spreken, kunnen wij denken aan een verandering die een voldongen feit is geworden, of wel aan een verandering die plaats heeft, of eindelijk aan een verandering die voorzien wordt. De eerste levert om zoo te zeggen een probleem van statica, de beide andere leveren problema's van dynamica op.

Zij die, vaak voorbarig, uit den discontoestand besluiten trekken ten aanzien van het al of niet gedeprecieerd zijn van het ruilmiddel, verheffen zich meestal niet boven het eerste vraagstuk, dat het eenvoudigst is, maar waarin zij niettemin de schromelijkste verwarring onderhouden. De reeds boven aangeduide dubbelzinnigheid in 
het spraakgebruik geeft eensdeels uitdrukking aan die verwarring en wordt anderdeels wederom de aanleiding voor anderen om in diezelfde verwarring te vervallen. Als het disconto hoog is, heet het geld duur. Duurte van geld ziet hier dus op de vergoeding voor het voor korten tijd in gebruik gegeven ruilmiddel. Maar als de koopkracht van het ruilmiddel groot is, heet het geld ook duur. Duurte van geld ziet hier dus op de waarde van het ruilmiddel in vergelijking van andere zaken die waarde hebben. De eene is de in geld uitgedrukte huurwaarde van geld, de andere is de in andere zaken uitgedrukte prijs waarvoor men geld koopt. Heeft de eene duurte met de andere iets uitstaande? Kan, - de eene factor gegeven zijnde, - daarin eene aanwijzing gelegen zijn om den anderen te leeren kennen? Immers neen. De vergoeding voor het gebruik van ruilmiddel wordt uitgedrukt door een verhouding tusschen de uitgeleende en de voor het gebruik betaalde geldsom. Hoe zal nu eene verandering in de ruilwaarde of koopkracht van het geld verandering kunnen brengen in de verhouding dier twee geldsommen? Wordt de waarde der eene in zekere reden verhoogd of verlaagd, dan rijst of daalt die der andere desgelijks en omgekeerd. Als honderd gulden thans op wissels of effecten geleend, door verandering in de koopkracht van het ruilmiddel een hoogere waarde vertegenwoordigen dan verleden jaar, dan zou men zeggen, moet de vergoeding voor het gebruik daarvan verhoogd worden. Maar men zou, aldus redeneerende voorbijzien, dat dezelfde oorzaak die de waarde der hoofdsom verhoogt die der vergoeding eene volmaakt evenredige verandering in denzelfden zin doet ondergaan, zoodat ceteris paribus het disconto onveranderd moet zijn gebleven, omdat niets zich heeft voorgedaan wat wijziging kon brengen in de verhouding dier twee geldsommen.

Maar ofschoon deze redeneering theoretisch geheel juist is, berust ze echter op de nooit volkomen met de werkelijkheid overcenstemmende onderstelling, dat het publiek hetwelk den rentestand bepaalt, de verandering die heeft plaats gehad begrijpt, op hare juiste waarde weet te schatten, en dat elk in staat is, overeenkomstig zijn belang te handelen. Aangezien dit een en ander echter nooit in aller deele het geval wezen zal, zullen er afwijkingen kunnen bestaan, maar natuurlijk zoowel in de eene als in de andere richting.

(Ik verzock den lezer zich nu altijd nog tot het disconto te bepalen, en maak hier ter loops de opmerking, in het vervolg 
van disconto sprekende, daarmede alle soorten van rente op korten termijn te omvatten.)

Het publiek dat den discontostand maakt, kan nl. bijv. eene mindere ruimte van leenbaar geld-kapitaal, die het gevolg is eener verminderde ruimte van het ruilmiddel, voor een primaire krapte der geldmarkt zelve aanzien, m. a. w. de ware oorzaak miskennen, of wel het kan die oorzaak erkennen maar daarbij overschatten. Gewoonlijk zelfs zal de taxatie der oorzaak op de geldmarkt wel niet nauwkeurig aan de veranderde verhoudingen ten aanzien van het ruilmiddel beantwoorden.

Wat zal nu gebeuren?

Stellen wij het geval dat op de geldmarkt de oorzaak eener in verhouding tot een voorafgaand tijdperk grootere krapheid niet wordt gezocht in de veranderde verhoudingen ten aanzien van het ruilmiddel, maar voor eene tijdelijke beweging der geldmarkt zelve wordt aangezien. De resultante der vraag en van het aanbod op de geldmarkt (want wij onderstellen natuurlijk ook dat de resultante der bewegende opinies miskenning der ware oorzaak is) zal nu wezen, dat het disconto naar evenredigheid van de andere omstandigheden, - die feitelijk geen hoogeren rentestaud wettigen, - betrekkelijk hoog zal zijn. Er zal slechts tot betrekkelijk hoogen prijs geld gehuurd kunnen worden, omdat men de krapheid voor eene eigene krapheid der geldmarkt houdt, terwijl zij inderdaad een breederen grondslag heeft en in het ruilmiddel wortelt. De miskenning der oorzaak van een anderen kant beziende, vind ik, dat er een in verhouding tot de wat het ruilmiddel betreft veranderde omstandigheden, te geringe lust zal bestaan om geld te koopen, id est andere zaken te verkoopen, en van daar weinig aanbod op de markt waar men geld verhuurt.

Omgekeerd het geval stellende, dat het publiek de oorzaak eener in verhouding tot een vorig tijdperk betrekkelijke krapheid der geldmarkt wel degelijk en terecht in de veranderde waarde van het ruilmiddel zoekt, maar die oorzaak in hare gevolgen voor de functie van het geld als ruilmiddel overschat, dan zal de beweging dor geldmarkt zich naar deze misvatting regelen. Er zal een in verhouding tot de veranderde omstandigheden betrekkelijk groote lust bestaan om geld te koopen, andere zaken te verkoopen. Van daar een betrekkelijk ruim aanbod op de geldmarkt en een laag disconto.

Mutatis mutandis zal een lage discontostand het gevolg zijn van miskenning, een hooge discontostand dat van overschatting eener verminderde koopkracht van het geld als oorzaak eener gevoelde 
ruimte op de geldmarkt. Maar, duor elkander genomen, is aan dergelijke misvattingen of dwalingen in de appreciatie van feiten slechts weinig gewicht toe te kennen. De misvatting in de eene richting heft die in de andere op, en het resultaat der schommelende beweging is ten slotte een evenwichtstoestand waarin het disconto zich zoodanig naar de veranderde koopkracht van het ruilmiddel heeft geschikt, dat de invloed van deze laatste nul is geworden. Dergelijke misvattingen en verkeerde appreciaties komen op de geldmarkt (en op elk ander economiseh gebied) ook voor buiten alle verband tot de ruilmiddelwaarde, en men is gewoon $z e$ in de theorie te verwaarloozen. Eene buiten verband tot eene veranderde koopkracht van het ruilmiddel staande meerdere of mindere ruimte op de markt van leenbaar geld kan evenzeer worden miskend of overschat, en zelfs zal de discontostand bij elke veranderde betrekking tusschen vraag en aanbod, ten slotte slechts het resultaat van allerlei schommelingen, die elk op een verkeerde schatting berusten, wezen kunnen. Maar als 't ons te doen is om den evenwichts-toestand te kennen, leggen deze bewegingen geen gewicht in de schaal. En in casu zal men zich met genoegzame juistheid uitdrukken, wanneer men zegt, dat eene verandering in de koopkracht van het ruilmiddel (de verandering als voldongen feit genomen) van geen beteekenis hoegenaamd is voor den discontostand.

Fn ditzelfde geldt, maar a fortiori, van den interest van op langen termijn geleende kapitalen. Ook hier hebben wij te doen met eene verhouding tusschen twee geldsommen, waarop door eene verandering in de waarde dier geldsommen geen invloed kan worden uitgeoefend, naardien beide in een zelfde verhouding getroffen worden. Stel, op zekeren tijd zijn $f 1000$ tegen eene vaste rente en onder bepaalde omstandigheden uitgezet wordende, cene vergoeding waard van $f 40$ per jaar, dan zullen op een anderen tijd, nadat het ruilmiddel inmiddels appreciatie heoft ondergaan, andere $f 1000$, tegen vaste rente en onder overigens gelijke omstandigheden uitgezet wordende, wel eene hoogere waarde vertegenwoordigen, maar de vergoeding van den kapitalist die dat deel van zijn kapitaal in gebruik geeft, behoeft daarom toch niet verhoogd te worden, aangezien de $f 40$ interest die hij vroeger voor $f 1000$ ontving, thans in dezelfde evenredigheid in waarde zijn toegenomen, zoodat hij zich - al het andere onveranderd gebleven zijnde - daarmede ook nu nog volkomen tevreden kan stellen. Aangezien voorts ruimte van geld als ruilmiddel niets te 
maken heeft met ruimte van te leen aangeboden kapitaal (als wij het leenbaar geld uitzonderen, gelijk hier tot onze onderstelling behoort) zoo kan zich een verandering in de koopkracht van het ruilmiddel op de eigenlijke kapitaalsmarkt in het geheel niet doen gevoelen, en bestaan hier dus ook de afwijkingen niet, die op de geldmarkt uit verkeerde appreciatie cener een fait accompli geworden verandering in de koopkracht van het ruilmiddel ontstaan.

Wij hielden ons tot hiertoe bezig met het evenwichtsvraagstuk, welke de invloed is dien een tot stand gekomen verandering in de koopkracht van het ruilmiddel op den rentevoet uitoefent; maar hoe staat ' $t$ nu met een verandering die bezig is tot stand to komen?

Aangezien er tijd noodig is alvorens alle economische verhoudingen voor welke eene verandering in de koopkracht van het ruilmiddel van beteekenis is, zich naar deze hebben geschikt, zoo is ' $t$ de vraag van waar de beweging uitgaat. Komt eene vermeerderde hoeveelheid ruilmiddel in de circulatie (hetzij door eene ruimere uitgifte van fiduciair ruilmiddel, hetzij door den invoer van het metaal dat tot ruilmiddel en waardemeter dient) langs den weg van aankoopen, dan zal aanvankelijk wel het absolute geldelijke bedrag van het op de geldmarkt ter leen aangeboden kapitaal hetzelfde wezen, maar de beteekenis er van (althans voor nieuwe transacties) zal verminderd zijn door de verminderde waarde van het ruilmiddel. Dientengevolge zal 't zijn als ware or meerdere krapheid op de geldmarkt, on het disconto zal stijgen. Het omgekeerde - daling van het disconto - zal geschieden, wanneer onttrekking aan de boeveelheid circuleerend medium plaats heeft langs den weg der handelstransacties. Aan de gevorderde hoeveelheid leenbaar kapitaal op korten termijn beantwoordt dan wederom niet volkomen meer dezelfde hoeveelheid ruilmiddel, maar thans is de op de geldmarkt aangeboden hoeveelheid ruilmiddel door de ten anzien van het ruilmiddel op de goederenmarkt veranderde omstandigheden integendeel in waarde gerezen, zoodat het feitelijke aanbod tegenover de vraag is toegenomen, en het disconto dalen zal.

Maar ofschoon de theorie vordert, dezen gang van zaken mogelijk te noemen, komt 't $m$ ij toch voor, dat het niet de gewone is. In den regel zal verandering in de verhouding van het ruilmiddel tot de in ruilmiddel waardecrbare zaken, door uitgifte of intrekking van fiduciair ruilmiddel, door in- of uitvocr van edel 
metaal, zich allereerst op de geldmarkt doen gevoelen. En in zooverre zou een betrekkelijk hoog disconto een teeken of aanwijzing moeten zijn voor cen toenemende koopkracht, een betrekkelijk laag disconto voor verminderende koopkracht van het ruilmiddel.

Dit alles geldt echter al weder uitsluitend wanneer wij van den rentestand der geldmarkt spreken. Op den rentestand der kapitaalmarkt in ruimeren zin oefent ook een in gang zijnde verandering in de koopkracht van het ruilmiddel geen invloed uit. Eene beweging welke leidt tot eene veranderde koopkracht in het ruilmiddel, kan wel uitgaan van de markt waarop het ruilmiddel als ruilmiddel werkt, en zij kan uitgaan van de markt van het leenbaar geld, maar zij kan niet uitgaan van een terrein dat aan het ruilmiddel vreemd is, de markt van den voor de productie beschikbaar gestelden verworven rijkdom. Dit terrein staat uit den aard der zaak buiten de beweging, en voor zoo ver het er mede in indirect verband staat, naardien ook kapitaal in ruimeren zin door middel van geld wordt overgedragen, treft elke wijziging in de waarde van het nominaal bedrag der kapitalen dadelijk in dezelfde verhouding de waarde van het nominaal bedrag der rente. Op de verhouding tusschen die twee factoren heeft zij echter geen invloed.

Brengt nu eene verandering in de koopkracht van het ruilmiddel, noch wanneer (beter gezegd: voor zoover) die tot stand gekomen is, noch terwijl (voor zoover) die nog bezig is tot stand te komen, verandering in den rentestand teweeg, zij heeft dien ten gevolge ook geen invloed op den geldprijs der tegen eene vaste rente uitgezette kapitalen. Bracht $z i j$ toch eene verandering teweeg in den geldsprijs van den interest, anders gezegd in de verhouding van rente tot hoofdsom, dan moest de harmonie tusschen de onder de nieuwe en de onder de oude ruilmiddelwaarde tot stand gekomen contracten van kapitaalleening zich herstellen door een rijzing of daling dor koersen. Maar aangezien wij hebben aangetoond, dat geen zoodanige invloed bestaat, staan ook de geldprijzen der tegen eene vaste rente uitgezette kapitalen geheel en al buiten de sfeer der ovcrigens niet onbeduidende gevolgen, welke eene verandering in de koopkracht van het ruilmiddel voor de maatschappelijke verhoudingen toweeg brengt.

Maar ook naar eene andere zijde de zaak beziende, vind ik hier geenerlei invloed. Elke verandering in den geldprijs der kapitalen zou moeten berusten op eene verandering in de reëele waarde van hoofdsom of rente of van beide. Maar olke compensatie 
die men bij koop of verkoop voor eene veranderde waarde der verschuldigde geldsommen, hoofdsom of rente zou willen geven, is reeds van zelf anwezig in de veranderde waarde der geldsom voor welke men kapitaal en rente of een van beide koopt. Zoodat ook van dien kant bezien de veranderde of veranderende koopkracht van het ruilmiddel allen invloed in de eene of de andere richting mist.

Anders is het natuurlijk gesteld (duidelijkheidshalve zij dit hier opgemerkt) met de kapitalen die niet tot eene vaste rente worden uitgezet, maar die de ondernemingswinsten genieten en de ondernomingsrisico's loopen, de marginal securities, zooals de Engelschen het met juistheid uitdrukken. Door elke verandering in de koopkracht van het ruilmiddel worden de inkomsten dezer kapitalen getroffen. De dividenden rijzen als de koopkracht af- zij dalen als die toeneemt, niet alleen doordien alle in geld uitgedrukte zaken en derhalve ook het verschil tusschen de ontvangsten en de uitgaven der ondernemingen een grootere of kleinere geldswaarde vertegenwoordigen naar gelang de koopkracht van het ruilmiddel af- of toeneemt, maar vooral omdat een deel dier uitgaven een vaste geldsom vorderen, namelijk juist de rente op de hiervoren genoemde vaste rentedragende kapitalen en eenige hiermede meer of min overeenkomende vaste lasten. Worden bij grooter koopkracht die in geld uitgedrukte dividenden geringer, dan wordt ook hun gekapitaliseerde geldswaarde geringer, m. a. w. de geldsom waarvoor de kans op dividend wordt gekocht. En voorts vertegenwoordigen de activa der onderneming, die een ander element zijn in den geldprijs der aandeelen, een geringere geldswaarde, en moet dus ook in zooverre de geldprijs der aandeelen dalen in geval de koopkracht van het ruilmiddel toeneemt.

Tot hiertoe vonden wij, dat de markt der op langen termijn uitgeleende kapitalen buiten allen invloed staat hetzij van eene verandering in de koopkracht van het ruilmiddel die een voldongen feit geworden is, hetrij van eene in gang zijnde verandering. De markt der op korten termijn geleende kapitalen (de geldmarkt), daarentegen bleek aan eenige schommelingen onderhevig te zijn die het gevolg zijn van de pogingen van het publiek om eene verandering die heeft plaats gehad to taxeeren; zij komt echter ten slotte tot rust in eene positie waarin de verandering welke heeft plaats gehad van geen blijvenden invloed blijkt geweest te zijn; en voorts is die markt onderhevig aan eenige schommelingen 
die het gevolg zijn van het verbroken evenwicht, terwijl de verandering zich voltrekt, maar om vervolgens onder gelijke voorwaarden tot rust te komen. Voor zoover hier echter eenige betrekking te vinden is tusschen koopkracht van het ruilmiddel en rentestand, is zij toch niet van dien aard, dat ik mij gerechtigd zoude vinden deswege van een derde element in den interest te gewagen. Eerstens hebben de goede economisten de invloeden die boven uiteengezet werden, met meerdere of mindere helderheid geanalyseerd zonder dit te doen; in de tweede plaats geldt dit alles uitsluitend ten aanzien van de rente op korten termijn, en kunnen zij vrij wel als eenige symptomen dezer toch reeds aan velerlei invloeden onderworpen grootere bewegelijkheid worden aangemerkt; en in de derde plaats werken die invloeden dadelijk als eene verandering in de betrekking tusschen de vraag naar en het aanbod van leenbaar geld, zoodat zij ook uit dit oogpunt beschouwd als bijomstandigheden van ondergeschikten aard in het eerste element in de rente $n$ de vergoeding voor het gebruik van het leenbaar geld", kunnen worden opgevat.

Tot hiertoe met ons onderzoek gevorderd zijnde, vinden wij derhalve geene aanleiding, meer dan de algemeen bekende twee elementen in den interest te onderscheiden: de vergoeding voor het gebruik en de assurantie tegen verlies.

Wij komen alsnu tot het onderzoek, welken invloed op den reutestand mag worden toegekend aan eene verandering in de koopkracht van het ruilmiddel die verwacht voordt. Wat vooraf ging heeft voornamelijk moeten dienen om het terrein voor de beantwoordiging van dit vraagstuk te effenen.

Beschouwen wij eerst de leeningen op korten termijn; daarna; gelijk $w i j$ in den loop van ons betoog steeds gedaan hebben, die op laugen termijn.

Eene te voorziene verandering in de koopkracht van het ruilmiddel kan op tweeërlei wijs invloed op het disconto uitoefenen. Verwacht het publiek verhoogde koopkracht i. e. lage prijzen, zoo zal de lust om artikels te verkoopen, geld te koopen, toenemen, van daar een ruim aanbod op de geldmarkt (d. i. op de markt waar geld gehuurd wordt) en een daling in het disconto. Wordt daarentegen verminderde koopkracht i. e. hooge prijzen te gemoet gezien, zoo zal integendeel de lust om artikels te koopen, geld te verkoopen, toenemen, van daar een ruime vraag op de geldmarkt on een rijzing in het disconto. Dit is de 
ééne wijs waarop die invloed zich openbaart. De andere bestaat hierin, dat het publiek, verhooging of vermindering der koopkracht van het ruilmiddel voorziende, eene verlaging van het disconto als geldgever zal toestaan of als geldopnemer eischen als compensatie voor de te verwachten hoogere reëele waarde der hoofdsom, of wel, omgekeerd, verhooging van het disconto als geldgever eischen of als geldopnemer toestaan als compensatic voor te verwachten geringere reëele waarde der hoofdsom. Men vatte dit niet zoo op, alsof deze twee wijzen waarop eene te voorziene verandering in de koopkracht van het ruilmiddel invloed op den discontostand kan uitoefenen elkander versterken zouden. Ze zịn twee zijden eener zelfde zaak en werken om zoo te zeggen alternatief, zoodat wanneer in de eischen der eene voorzien is, ook die der andere zijn vervuld on omgekeerd. En te zamen bewerken zij, dat eene te voorziene verhooging in de koopkracht van het ruilmiddel verlaging van het disconto, eene te voorziene verzwakking dier koopkracht daarentegen verhooging van het disconto ten gevolge heeft.... of liever vooraf doet gaan.

Letten wij nu op de eigenlijk gezegde kapitaalmarkt.

Zonder te zeggen, dat niet ook hier eene te voorziene vermeerdering of vermindering in de koopkracht van het ruilmiddel haren invloed uitoefent, als van beteekenis zijnde voor het koopen of verkoopen van geld of waren, treedt hier toch deze beteekenis der zaak meer op den achtergrond. Op de kapitaalmarkt in ruimeren zin is het geld wel het middel waardoor kapitaal wordt overgedragen, maar niet het dadelijke voorwerp dat begeerd wordt, noch ook dat men van de hand wil doen om in waarde rijzende goederen in de plaats daarvan optenemen. De hoofdsom wordt hier voor langere belegging gezocht en aangeboden, meer om de voordeelen die met het kapitaal te behalen zijn door 't aan de productie ten gebruike te geven, dan wel om de winsten die to behalen zijn met speculatie op rijzing of daling van waarde. Maar ofschoon dit waar is, heeft ook hier eene te voorziene verandering in de koopkracht van het ruilmiddel een belangrijken invloed op den rentestand. Want terwijl de toekomstige waarde van het ruilmiddel waarin het kapitaal wordt overgedragen, wel niet het hoofdmoment der speculatie, maar toch een bijkomende omstandigheid van groot gewicht is, treedt de waarde der rente zelve hier meer op den voorgrond en wordt een element van beteekenis in de berekening.

Ondersteld, het publiek verwacht verhooging in de koopkracht van het ruilmiddel, dan zal degene die een kapitaa! tegen eene 
vaste rente uitzet, geneigd zijn, met eene lagere rente tevreden te zijn, dan wanneer zoodanige verwachting niet bestond en men op onveranderde koopkracht rekende. Men zal met eene geringere rente tevreden zijn, eerstens omdat de rente zelve later eene hoogere reëele waarde vertegenwoordigen zal, anderdeels omdat ook de hoofdsom bij de aflossing eene hoogere waarde zal vertegenwoordigen en de geldschieter deswege in den interest eene compensatie zal willen toestaan.

Van den anderen kant: ondersteld, men verwacht vermindering der koopkracht van het ruilmiddel; dan zal de geldschieter celeris paribus een hoogeren interest bedingen als vergoeding voor de aanstaande mindere waarde van het in geld uitgedrukte bedrag van den interest en als vergoeding tevens voor de mindere intrinsieke waarde ter hoofdsom ten tijde dat die zal worden afgelost.

De harmonie tusschen de onder de veranderde vooruitzichten belegde kapitalen en die welke onder de vorige vooruitzichten uitgezet werden, wordt nu hersteld door rijzing of daling van den koers, waardoor voor den nieuwen verkrijger de aangekochte kapitaal-belegging dezelfde voordeelen als de nieuwe belegging aanbiedt. Daalt de rentevoet, zoo rijzen de koersen, stijgt de rentevoet zoo dalen ze. Dit is dezelfde beweging die het evenwicht herstelt in alle gevallen waarin de rentevoet rijst of daalt ten gevolge van invloeden die de beide andere elementen (de huur en de assurantie) aandoen. En de verkooper eener bestaande schuldvordering realiseert voor zich zelven de winst of het verlies uit veranderde omstandigheden voortvloeiende, en wat speciaal de toekomstige koopkracht van het ruilmiddel betreft, de veranderde vooruitzichten daaromtrent.

Ik sprak daar van de huur en de assurantie als van "de beide andere elementen" in den interest, en inderdaad meen ik nu in verandering der geldswaarde welke vourzien wordt een derde element in de rente te hebben gevonden. De beide bekende elementen, de zuivere rente en de assurantie, zijn zonder uitzondering positief, het derde element, de vergoeding der te voorziene verandering in de geldswaarde, kan zoowel positief als negatief zijn. Bij dalende geldswaarde is het positief, bij rijzende negatief. Of om het anders uittedrukken, vergoeding voor het gebruik van het kapitaal en assurantie tegen verlies stellen den interest samen, die door de verwachting omtrent de toekomstige koopkracht van het ruilmiddel positief of negatief gewijzigd, verhoogd of verlaagd worden kan. 
Om kort te gaan, theoretisch althans, mag men aannemen, dat het derde element ten allen tijde in den interest voorkomt, al kan men van dit, evenmin als van de andere elementen, de portée nauwkeurig bepalen.

Maal ik voorzie eene tegenwerping. Misschien zal men wel willen toegeven, dat het hier ontwikkelde element in theorie in den interest aanwezig mag worden geacht, maar dat 't in de praktijk toch van geringe beteekenis moet zijn, van zoo geringe beteekenis zelfs, dat men 't vrij mag verwaarloozen, omdat het publiek dat den rentestand bepaalt, geen overtuiging heeft omtrent de toekomstige koopkracht van het ruilmiddel.

Oogenschịjnlijk is daarvoor veel te zeggen. Maar bij nader inzien zal men moeten toestemmen, dat het optreden van de publieke opinie hier niet wonderlijker is dan in vele andere gevallen. Dat waarmede wij hier te doen hebben, behoort zelfs niet tot de minst eenvoudige. $\mathrm{Om}$ de tegenwerping volledig te wederleggen, zou ik een geheele verhandeling moeten schrijven over het ontstaan der publieke opinie of over het onbewuste in de publieke opinie, een interessant onderwerp ongetwijfeld, maar te rijk om 't hier ter loops af te doen. Voor ons tegenwoordig doel zij 't voldoende er op te wijzen, dat de publieke opinie zich op tallooze wijzen duidelijk uitspreekt, zonder dat de individueele leden van het publiek zich zelven rekenschap weten te geven van de gronden waarop die opinie steunt.

Tot de moeilijkste gevallen rekenen wij die, waarin de algemeene opinie verstandiger blijkt te zijn dan die van de bizondere personen, zoodat de besten en meest ontwikkelden eerst door nasporing haar juist inzicht leeren waardeeren om zich ten slotte aan haar ook weder te onderwerpen. Dat het publiek als een geheel genomen vrij geprononceerde denkbeelden heeft omtrent de nuttigheid en doelmatigheid van sommige maatschappelijke verhoudingen, blijkt uit het voortleven van gestrenge beginsels van moraal, hoe dikwijls die ook door particulieren en regeerders worden miskend en hoe moeielijk het ook zij, de ware ratio dier beginsels terug te vinden, zoodat de particuliere opinies omtrent weinig onderwerpen meer verdeeld zijn dan juist omtrent de grondslagen der moraal.

Het geval waarmede wij hier te doen hebben, behoort echter tot eene andere groep van uitingen der publieke opinie, die naar 't mij voorkomt, van eenvoudiger aard zijn, namelijk die waarin wij met meerdere of mindere waarschijnlijkheid het bestaan kunnen aanwijzen eener bij de best ingelichten aanwezige overtuiging, 
krachtig genoeg om het groote publiek bij zijn handelingen in een zekere richting te leiden. Een zoodanig geval doet zich bijv. voor, als wij zien, dat ondanks vele, binnen zekere grenzen mogelijke nitzonderingen, de beursprijzen der effecten vrij gevoelige meters zijn voor de waarde der fondsen met het oog op rentabiliteit en soliditeit. Hier mogen wij stellen, dat er ten opzichte van elk fonds een groep van beter ingelichten bestaat, die zich haast, van elk voordeel in den koers door aankoop, van elk nadeelig verschil door verkoop te profiteeren. In dien trant stelle men zich ook den gang van zaken voor, als de verwachting omtrent de toekomstige koopkracht van het geld invloed op den rentestand uitoefent. Eenige centra van waar zekere terughoudendheid in de belegging van nieuwe kapitalen of wel een zekere geneigdheid om met een geringeren interest tevreden te zijn uitgaat, zijn voldoende om de geheele beweging aan den gang te brengen.

Maar ook afgezien daarvan, is van elke ingetreden verandering in de verhouding van het ruilmiddel tot de in geld waardeerbare zaken eene verandering der prijzen een eerste symptoom. Deze beweging eenmaal aan den gang zijnde, vormt zich een publieke opinie ontrent het aanhouden der beweging gedurende eenigen tijd. Zoo koestert het publiek meeningen omtrent toekomstige geldprijzen, welke meeningen denzelfden invloed hebben op den rentestand als die het gevolg zoude zijn van eene overtuiging omtrent de toekomstige ruilmiddelwaarde.

Wel beschouwd is de werking der publieke opinie in ons derde element niet wonderlijker dan in de beide andere. Hoe weinigen onderscheiden werkelijk, als geldgevers optredende, het andeel voor assurantie van dat voor huur, in den interest waarvoor zij tot belegging in elk bizonder geval bereid zijn? Hoe weinigen bepalen de grootte van elks aandeel in elk bijzonder geval? Evenmin als de individueele leden van het publiek eene meening hebben omtrent de toekomstige ruilmiddelwaarde, evenmin hebben zij eene meening omtrent hetgeen een voldoende vergoeding is voor afstand te doen van het genot, dat uit de vertering van het kapitaal zoude voortvloeien, en evenmin hebben zij eene meening, noch omtrent de kansen van verlies in verschillende gevallen, noch omtrent de vergoeding die aan eene bepaalde verhouding van kansen beantwoordt. En toch blijkt bij onderzoek, dat de taxatie der kansen van verlies met vrij groote nauwkeurigheid plaats heeft, en dat omtrent eene voldoende vergoeding voor het gebruik en een 
voldoende assurantie-premie, binnen bepaalde grenzen eene vrij goed gevestigde overtuiging bestaat.

Met een en ander acht ik het geopperde bezwaar voldoende beantwoord, en de conclusie gewettigd, dat het derde element in den interest niet alleen theoretisch anwezig is, maar dat 't ook van genoegzaam gewicht is om 't niet te mogen verwaarloozen. Integendeel geloof $i k$, dat 't dienen kan om ons veel wat tot heden minder verstaanbaar scheen te doen verklaren.

Maar alvorens hiertoe over te gaan, wil ik trachten, het derde element in den interest zijn plaats bij de twee andere aan te wijzen, m. a. w., nadat analytisch de deelen gevonden zijn, ook de daaraan beantwoordende synthesis tot stand brengen.

Het voornaamste, het overwegende element, blijft in ieder geval de eigenlijke vergoeding voor het gebruik van het kapitaal. Het bedrag daarvan hangt af van het aanbod van en van de vraag naar kapitaal, hetzij dat wij daarbij het oog vestigen op de kapitalen op langen termijn, hetzij dat wij meer bepaaldelijk aan de geldmarkt denken.. Door tal van schommelingen heen zal de rente eindelijk daar staan blijven, waar het aanbod juist tegen de vraag opweegt, d. i. daar waar voor een aanbod A het minimum belooning ligt waartegen het aan vaste belegging de voorkeur geeft boven deelneming aan de ondernemingswinten of boven vertering, en voor eene vraag $\mathbf{A}$ het maximum belooning dat $\mathrm{zij}$ wil toestaan, en waartegen zij aan productie met vreemd kapitaal de voorkeur geeft boven arbeid zonder zoodanig kapitaal. Deze factor is zonder uitzondering positief en kan nooit beneden zeker minimum dalen, waar beneden alle anbod van kapitaal zou ophouden. Maar over het algemeen genomen heeft de huur van het kapitaal een neiging om to dalen (tot dit minimum meer en meer te naderen), aangezien bij toenemende beschaving de blijvende waarde van behoud van het kapitaal in de schatting der eigenaars steeds meer beteekenis erlangt tegenover het genot dat door dadelijke consumptie te verkrijgen is.

De in rangorde tweede factor in de rente moet m. i. de assurantie tegen verlies blijven. Dit element kan mede nooit negatief worden, maar wel tot nul dalen of althans uiterst klein worden. De interest kan nooit dalen beneden hetgeen hij wezen zou zonder eenige assurantie tegen verlies, als bloote vergoeding voor ontzegging van genot aan de zijde van den geldschieter; maar de aangeboden zekerheid kan zoo groot zijn, dat de huur van het 
kapitaal niet of nagenoeg niet met eenige assurantie wegens mogelijk verlies behoeft verhoogd te worden. Naar gelang in eenig land het peil der zedelijkheid rijst, de betrouwbaarheid van beloften en contracten toeneemt, de rechtszekerheid grooter wordt, maar vooral naar gelang de rechtschapenheid van den bizonderen geldopnemer hooger mag worden aangeslagen, en allermeest naar gelang het zakelijke onderpand meer voldoende is, wordt ' $t$ voor den geldgever minder noodzakelijk, eene premie tegen mogelijk verlies van kapitaal of rente in rekening te brengen. Het assurantieelement kan derhalve zeer het nulpunt naderen, ofschoon 't strikt genomen nooit verdwijnen en a fortiori nooit negatief worden kan.

Anders is 't met het derde element in den interest, waarop 't mijne bedoeling was in deze weinige bladzijden de aandacht van de beoefenaars der Staathuishoudkunde te vestigen: de verwachting eener aanstaande verandering in de koopkracht van het ruilmiddel. Aangezien deze kan zijn in de richting van eene mindere zoowel als in die van eene grootere koopkracht, kan zij den rentevoet dic overigens bestaan zou zoowel verlagen als verhoogen m. a. w. zoowel negatief als positief zijn.

Om kort te gaan: de eigenlijke vergoeding voor het gebruik van het kapitaal is altijd positief en niet vatbaar om beneden zekere grens te dalen; het tweede element, de assurantie, is altijd positief, maar in staat om tot een punt te dalen, waarop het nagenoeg verwaarloosd worden mag; het derde element eindelijk, de verwachting omtrent de toekomstige koopkracht van het ruilmiddel, kan zoowel negatief als positief werken.

Ligt nu in het vorenstaande opgesloten, dat over het algemeen genomen, tijden van rijzende geldswaarde tevens tijden van een lagen rentestand, en omgekeerd tijden van dalende geldswaarde tevens tijden van een hoog disconto en van een hoogen rentestand zijn, hiermede is dan ook dit verband verklaard, voor zoover ' $t$ empirisch is gegeven.

In section 9 van het $2 \mathrm{e}$ boek van het $1 \mathrm{e}$ hoofdstuk zijner Principles of Political Economy maakt Malthus melding van de reductie van de rente der Engelsche staatsschuld van 4 op 3 pCt., die in het midden der $18 \mathrm{e}$ eeuw plaats had, waartoe twee omstandigheden toenmaals aanleiding gaven, nl. een algemeen buitengewoon lage rentestand, samengaande met eenen toenmaals be. trekkelijk evenzeir lagen prijs van het koren. En hij verklaart dat samengaan uit een „overvloed van kapitaal, gepaard met gebrek 
aan vraag naar levensmiddelen." Malthus' verklaring (die eigenlijk zelve niet anders inhoudt dan de vermelding, dat de betrekking tusschen vraag en aanbod op de kapitaalmarkt zoodanig was, dat de huur van kapitaal betrekkelijk laag kon zijn, terwijl te gelijker tijd die verhouding op de graanmarkt zoodanig was, dat ook de geldprijs van koren betrekkelijk laag kon zijn, - geene verklaring echter van het verband tusschen die twee zaken inhoudt) boezemt ons weinig belangstelling in, wèl zijn mededeeling van het feit. In eerste helft der vorige eeuw bereikten nl. de Engelsche 3 pCts. een hoogeren prijs dan in eenig later tijdperk. In Juni 1737 noteerden zij 107, en de 3 pCts. Consols bereikten den hoogsten koers in 1752 kort na haar ontstaan uit andere schuldsoorten.

In een niet lang geleden verschenen verzameling Essays van Stanley Jevons $\left(^{*}\right)$ vind ik een groot diagram, den prijs aanwijzende van de Engelsche staatsfondsen, den prijs der tarwe en den stand van het disconto, van maand tot maand van af 1731 . ${ }_{n}$ On examining the above diagram from the year 1824, zegt naar aanleiding daarvan Prof. Foxwell, it will be obvious that a rise in the rate of discount usually follows a rise in the price of wheat. This is explained by considering that wheat, being the principle article of food, constitutes the most important part of the capital of the country. Its scarcity should naturally bo followed by the indications of a scarcity of capital."

Ook ditmaal interesseert ons de verklaring niet, die hier van het versehijnsel gegeven wordt, naardien 't mij alleen te doen is, om wel te doen uitkomen, dat buiten de theorie van een derde element in den interest om en op grond van gegevens die verzameld waren met een geheel ander doel, het verband geconstateerd is tusschen lage prijzen en lage rente, hooge prijzen en hooge rente. De door Foxwell geopperde verklaring kan onmogelijk geacht worden voldoende te zijn. Immers, al wil men (wat do beteekenis der zaak voor "the capital of the country" zou verhoogen) in de plaats van duurte van graan een algemeene duurte lezen, dan nog bestaat er geen verband tusschen de geldswaarde van het kapitaal des lands en de betrekking tusschen de vraag naar en het aanbod van huur van dat kapitaal.

Maar ik laat Foxwells verklaring rusten, en keer tot de feiten terug.

(*) W. Stauley Jevous, Investigations in Currency and Finance, ed. by H. S. Foxwell M. A. London Macmillan \& Co. 1884. 
Ik doe hier een opgaaf volgen van den loop der goederenprijzen sedert 1845 en van het gemiddeld disconto bij de Engelsche Bank in dienzelfden tijd. Voor de jaren 1845 tot 1869 bedien ik mij wat de goederenprijzen betreft van een meetkunstig gemiddelde der ratio's ten opzichte van het gemiddelde der jaren 1845-50, ontleend aan het bovengenoemde werk van Stanley Jevons. Voor de prijzen van 1870 af bedien ik mij van het zoogenaamde indexnummer van the Economist, zijndo de eenvoudige som der ratio's voor 22 categoriën van goederen op 1 Jan. van elk jaar ten opzichto van den gemiddelden prijs in de jaren $1845-50$. Voor mijn tegenwoordig doel zijn de beide opgaven even voldoende.

\begin{tabular}{|c|c|c|c|c|c|}
\hline Jaar. & $\begin{array}{l}\text { Gemidd prijs } \\
\text { der goederen. }\end{array}$ & $\begin{array}{c}\text { Gemiddeld } \\
\text { disconto. }\end{array}$ & Jaar. & $\begin{array}{l}\text { Gemidd, prijs } \\
\text { der goederen. }\end{array}$ & $\begin{array}{l}\text { Gewiddeld } \\
\text { disconto. }\end{array}$ \\
\hline 1845 & 104 & 2.62 & 1869 & 3530 & 3.25 \\
\hline 1846 & 105 & 3.34 & 1870 & 2689 & 3.12 \\
\hline 1847 & 111 & 5.33 & 1871 & 2590 & 2.87 \\
\hline 1848 & 94 & 4.- & 1872 & 2835 & 4.12 \\
\hline 1849 & 90 & 2.92 & 1873 & 2947 & 4.75 \\
\hline 1850 & 92 & 2.50 & 1874 & 2891 & 3.75 \\
\hline 1851 & 92 & $3 .-$ & 1875 & 2778 & 3.25 \\
\hline $185^{\circ}$ & 94 & 2.08 & 1876 & 2711 & 2.62 \\
\hline 1853 & 111 & 3.50 & 1877 & 2723 & 2.87 \\
\hline 1854 & 121 & 5.12 & 1878 & 2529 & 3.75 \\
\hline 1855 & 118 & 4.75 & 1879 & 2902 & 2.37 \\
\hline 1856 & $122 \frac{1}{2}$ & 5.75 & 1880 & 2538 & 2.75 \\
\hline 1857 & $120^{\circ}$ & 6.75 & 1881 & 2376 & 3.50 \\
\hline 1858 & 114 & 3.25 & 1880 & 2435 & 4.12 \\
\hline 1850 & 116 & 2.75 & 1883 & 2342 & 3.56 \\
\hline 1860 & 118 & 4.25 & 1881 & 2221 & 2.95 \\
\hline 1861 & 115 & 5.25 & 1885 & 2098 & 2.84 \\
\hline 1862 & 113 & 2.50 & 1886 & 2048 & $\cdots$ \\
\hline 1863 & 113 & 4.50 & & & \\
\hline 1864 & 113 & 7.50 & & & \\
\hline 1865 & 113 & 4.75 & & & \\
\hline 1866 & 116 & $7 .-$ & & & \\
\hline 1867 & 114 & 2.50 & & & \\
\hline 1868 & 116 & 2.25 & & & \\
\hline 1869 & 115 & 2.25 & & & \\
\hline
\end{tabular}

Wil men uit deze cijfers iets ten aanzien van ons onderwerp leeren, dall moet men sommige zaken in aanmerking nemen. Eerstens is voor eene blijvende rijzing of daling in de koopkracht van het ruilmiddel de discontorente een veel slechter matstaf dan de rente van op langen termijn uitgeleende kapitalen. Zij tracht uit den aard der zaak meer vourdeel te trekken uit de snelle rijzingen of dalingen. Daarenboven is zij onderhevig aan allerlei andere tijdelijke en plaatselijke invloeden, als den stand der handelsbalans, geruehten van oorlog, plaatselijke behoefte aan ruilmiddel voor de afwikkeling van reeds lang geleden afgesloten 
transactiën, de bij bankdirectiën heerschende denkbeelden omtrent de noodzakelijkheid eener bescherming van den goudvoorraad, en wat dies meer zij, omstandigheden, te talrijk om hier alle te vermelden. Zoo houde men in het oog, dat het jaar 1847 een crisisjaar was, waarin zelfs eene maand lang een disconto van $10 \mathrm{pCt}$. heeft bestaan. Ditzelfde geldt van het jaar '57, dat zich o. a. tegen het einde door talrijke faillissementen in de Vereenigde Staten kenmerkte, en waarin dezelfde hooge discontostand in December bereikt werd, terwijl het jaar 1861 dat was van den Amerikaanschen burgeroorlog. 1864 was een grïnderjaar en in 1866 deed, ditmaal omstreeks het midden des jaars, een paniek het disconto rijzen, -- het was het jaar van den Duitsch-Oostenrijkschen oorlog. Het jaar 1873 was dat waarvan een nieuwe gedruktheid in den handel uitging, haar oorsprong nemende in de ineenstorting der Amerikaansche speculatie. In 1878 was de val der City of Glasgow Bank de oorzaak, dat tegen het einde des jaars het disconto met snelheid tot $6 \mathrm{pCt}$. steeg, en dat laatste deed zich voor in het begin van 1882 als een gevolg der paniek aan de Parijsche beurs, en van den val der Union Générale.

Als wij nu den boven medegedeelden staat nauwkeurig beschouwen, dan vinden wij niet alleen in het disconto den duide. lijken terugslag op de goudontdekkingen van de jaren 1851 en volgende, maar wij vinden nagenoeg elke prijsverhooging of -verlaging in het disconto afgespiegeld.

Het jaar 1848 moeten wij nog eenigzins onder den invloed rekenen te staan van het crisisjaar 1847. Neemt men dit in aanmerking, dan bevindt men, dat de lagere prijzen van 1848 tot 1852 zich in het disconto uitspreken. Daarop volgen de hoogere prijzen die uitdrukking geven aan de genoemde goudontdekkingen; en wij zien zelfs van jaar tot jaar, en nauwkeuriger dan wij hadden durven verwachten, de eene beweging de andere volgen. Wel schijnt in 1857 het disconto gemiddeld buitengewoon hoog geweest te zijn, maar wij herinneren ons aanstonds het boven omtrent dat jaar opgemerkte, zoodat ons dit minder verwondert. Na 1857 vinden wij weder een vrij nauwkeurige harmonie tusschen goederenprijzen en disconto, behoudens wat betreft het jaar van den Amerikaanschen burgeroorlog 1861 , en de periode van 1863 tot en met 1866, waarin wij eerstens vinden eene behoefte aan gereed geld waar de oprichting van maatschappijen tot speculatie ontaardt en vervolgens dezelfde behoefte waar een overdreven credietstelsel eene moeielijke verrekeningperiode in het leven roept. 
Overgaande tot de jaren na 1866 , van waar de appreciatie van het goud ongeveer haren oorsprong neemt, vinden wij, behoudens het omtrent de jaren 1873,1878 en 1882 opgemerkte, een bijna nauwkeurig parallelisme tusschen de rijzende en dalende bewegingen der prijzen en die van het disconto. Er is bijna geen rijzing die zich niet door hooger, bijna geen daling die zich niet door lager disconto kenbaar maakt.

Terwijl deze bewegingen der geldmarkt nu in volkomen harmonie zijn met mijne theorie van een derde element in den rentevoet, in zooverre als deze soort van beweging op grond der theorie verwacht moest worden, en derhalve ook van den anderen kant, deze beweging gegeven zijnde, de theorie volkomen voldoende is om het verschijnsel te verklaren, is daarmede niet minder in harmonie het uitblijven van verandering in den discontostand in geval van blijvende verandering in de koopkracht van het ruilmiddel. Terwijl nl. alle kleinere bewegingen der goederenmarkt zich uitspreken in die der geldmarkt, vinden wij, terugziende op den aanvang der periode, die wij als eene van appreciatie yan het goud hebben leeren kennen, do sehommelingen om zoo te zeggen binnen dezelfde grenzen plaats grijpen waarbinnen zij zich thans bewegen. De huur van het geld op korten termijn richt zich telkens naar de binnen kort te verwachten verschillen, maar of dit verschillen zijn tusschen betrekkelijk hooge dan wel tussehen betrekkelijk lage cijfers doet voor de waarde van het instrument waarmede van die verschillen partij wordt getrokken (het leenbaar geld), niets af.

Daarentegen vordert onze theorie van den anderen kant, dat de rente van op langen termijn uitgeleende kapitalen buiten den invloed sta van de kleine, snelle, bewegingen der goederenprijzen, maar zich gevoelig betoone voor elke blijvende verandering in die prijzen, welke als een appreeiatie of depreciatie van het ruilmiddel mag worden opgevat.

Welnu. Ook dit verband is aanwezig. Wij behoeven, om er ons van te overtuigen, slechts in aanmerking te nemen, dat elke rijzing of daling in den rentestand voor nieuw belegde kapitalen, zich ten aanzien van de oude kapitalen uitspreekt door eene verhooging of verlaging van den koers. Voor de houders dier oude kapitalen heeft die koersverandering echter geen dadelijk belang, aangezien zij steeds verkoopende winnen of verliezen, wat zij koopende wederom verliezen of winnen. Beteekenis heeft die koersverandering voor hen eerst dan, wanneer zij uit de klasse der ren- 
teniers tot eene andere klasse, bijv. die der ondernemers, overgaan, of wanneer de schuldenaar van zijn recht tot aflossing gebruik makkt, en den schuldeischer door eene conversie dwingt, met eene geringere rente genoegen te nemen.

In 1852 , toen de goudontdekkingen haren invloed op de prijzen en op den rentestand nog niet hadden doen gevoelen, overschreed de prijs der Engelsche Consols de 100 pCt. Na vele schommelingen ten gevolge van politieke of andere invloeden die een tijdelijk groot aanbod op de fondsenmarkt veroorzaakten, was de koers in 1866 aanmerkelijk beneden 90 pCt. gedaald. Dit jaar was tevens een jaar van paniek, en van toen af volgde spoedig een aanmerkelijk herstel, maar de koers raakte de $95 \mathrm{pCt}$. eerst weder in 1875, totdat in 1881 de $100 \mathrm{pCt}$. opnieuw werd overschreden. Derhalve: depreciatie van het goud sedert 1852 met daling der koerseu, i. e. rijzing van den rentestand; - appreciatie van het goud sedert 1866 met rijzing der koersen i. e. daling van den rentestand, en eindigende in een algemeene conversie-koorts.

Kan alzoo het verband dat ik behoorlijk geconstateerd acht, gelijk ik meen nitvoerig te hebben aangetoond, niet verklaard worden, noch uit reeds veranderde noch ook uit nog veranderende prijzen of ruilmiddelwaarde, het kan daarentegen volkomen verklaard worden uit de verwachting, welke wij steeds eenigermate onderstellen mogen aanwezig te zijn, omtrent toekomsizge geldswaarde, ware 't ook, dat die verwachting geen dieperen grondslag heeft dan dat op de voortzetting gedurende eenigen tijd gerekend wordt van eene eenmaal ingetreden beweging.

Uit een en ander volgt nu ook, in hoe verre wij in de discontoen rentestanden eene aanwijzing vinden mogen voor de aanwezigheid eener in vergelijking tot eene voormalige periode grootere of geringere koopkracht van het ruilmiddel.

Bijna uitsluitend kunnen wij die slechts indirect daarin vinden.

Direct leert ons noch de rente der kapitalen op korten noch die der kapitalen op langen termijn iets omtrent de ruilmiddelwaarde. Ten aanzien van eene veranderde ruilmiddelwaarde die is tot stand gekomen, mag men koorts aannemen, dat de misvattiugen van het publiek omtrent de oorzaken eener met het ruilmiddel samenhangende meordere of mindere krapheid op de geldmarkt tegen elkander opwegen; zij geven geene resultante. Van den anderen kant, ofschoon niet uit den rentestand op langen, is er uit den rentestand op korten termijn iets te leeren omtrent 
eene verandering in de koopkracht van het ruilmiddel die bezig is plaats te grijpen. Het is hierbij echter steeds eenigzins onzeker, in welke richting de discontostand ons wijst, omdat wij niet voldoende kunnen nagaan, hoo eene betrekkelijke ruimte of krapheid der geldmarkt is ontstaan. Niettemin zou, wanneer geen derde element in den interest ware aan te wijzen naast de zuivere huur en de assurantie, een hoog disconto meer of min op eene aan den gang zijnde appreciatie, een laag disconto meer of $\min$ op eene aan den gang zijnde depreciatie henen wijzen. Wijl er evenwel een derde element in den interest moet worden aangenomen, waarvan eene voorzichtige deductie in verband met eene behoorlijke analysis van feiten ons het bestaan overtuigend heeft aangetoond, en krachtens hetwelk zoowel de rente op korten als die op langen termijn zich naar eene in de toekomst waarschijnlijk geachte koopkracht van het ruilmiddel schikt, zoo wijst ons een lage rentestand direct op eene verwacht wordende appreciatie, en cen hooge rentestand op eene verwacht wordende depreciatie van het ruilmiddel, en indirect de eerste op appreciatie, de tweede op depreciatie zelve, omdat een verwachting die bestaat het vermoeden wettigt, dat $z \mathrm{ij}$ in eene reeds bestaande beweging hare aanleiding vindt.

Het derde, hier meer of mill uityoerig door mij beschreven element, is dus niet alleen in theorie in de rente aanwezig, maar feitelijk van genoegzame beteekenis om het niet te mogen verwaarloozen, de theorie is volkomen met do foiten in overeenstemming en verklaart veel wat tot nu toe niet verklaarbaar scheen. Het werpt een nieuw licht op velerlei economische betrekkingen.

Voor zoover ik heb kunnen nagaan, is dit derde element in den interest door geen enkel economist opgemerkt. De eenige aanwijzing die ik er van heb kunnen vinden, is eene passage in de Principles of Pol. Economy van J. S. Mill (B. III, Ch. XXII, $\S 4$ ), waar hij zich als volgt uitlaat: „We thus see that depreciation, merely as such, while in process of taking place, tends to raise the rate of interest: and the expectation of further depreciation adds to this effect: because lenders who expect that their interest will be paid, and the principal perliaps redeemed, in a less valuable currency than they lent, of conrse require a rate of interest sufficient to cover this contingent loss". (*)

Deze aanhaling, te vinden op pag. 391 van de people's edition

(*) Ik cursiveer. 
(1885) die een getrouwe nadruk van de zesde editie is, heeft betrekking op eene verandering in de koopkracht van het ruilmiddel die langs den weg van ruilingen tot stand komt, en bevat inderdaad de erkenning in beginsel van hetgeen ik het derde element in den interest genoemd heb. Ik waag echter de overtuiging uit te spreken, dat Mill toch inderdaad de beteekenis er van niet volkomen duidelijk heeft ingezien, naardien hij er eerstens slechts melding van maakt in verband met de rente op korten, niet met betrekking tot die op langen termijn, en voorts dat verband nog slechts als eene omstandigheid van ondergeschikten aard beschouwt, die den invloed op den discontostand, door eene aan den gang zijnde verandering in de koopkracht van het ruilmiddel uitgeoefend, eenigermate versterkt.

Maar van den anderen kant geeft het gezag van Mill een grooten steun aan mijne theorie. Eenmaal in beginsel toegestemd zijnde, dat de verwachting die bij het publiek bestaat omtrent de toekomstige koopkracht van het ruilmiddel, niet zonder invloed is op den discontostand, zullen mijne verdere gevolgtrekkingen moeielijk af te wịzen zijn. Daartoe wordt slechts gevorderd dat men inzie, hoe zeker en bepaald de invloed dezer verwachting is, in vergelijking tot het onzekere en onbepaalde, beurtelings in de eene en in de andere richting werkende, van den directen invloed eener zich voltrekkende verandering in de ruilmiddelwaarde op de geldmarkt. En voorts, dat diezelfde verwachting vooral van niet geringer beteekenis is voor den rentestand van op langen termijn uitgeleende kapitalen dan voor het disconto.

Amsterdam.

$\mathrm{J}_{\triangle C O B}$ DE $\mathrm{H}_{\triangle A S} \mathrm{~J}_{\mathrm{R}}$.

Naschrift der Relactie. Ook bij instenming met het betoog van den geachten inzender omtrent het verband tusschen verwachte wijziging in de waarde van het ruilmiddel, en den interest, - zou men kunnen vragen, of de rangschikking als derde element van den interest wel juist is te achten?

Immers de benaming nassurantie tegen verlies" omvat in casu velerlei, - nl. niet alleen de meer of minder solvabiliteit van den persoon des geldopnemers, doch ook de onzekerheid welke in den aard der onderneming, in den stand van den algemeenen 


\section{5}

handel, in den politieken gezichteinder enz. haren grond kan vinden. De oorzaken van onzekerheid kunnen veelzijdig zijn. Kan men nu als eene zoodanige ook op de gebeurlijkheid van veranderde ruilmiddelwaarde verwijzen, dan moge daaruit blijken, hoe ruim het terrein van dien tweeden factor is, maar dan volgt, onzes inziens, daaruit nog niet, dat er hier een derde bestanddeel van den interest te onderscheiden valt, dat tot heden werd voorbijgezien, en dat principieel van de zóogenaamde verzekeringspremie zou verschillen.

Red. 